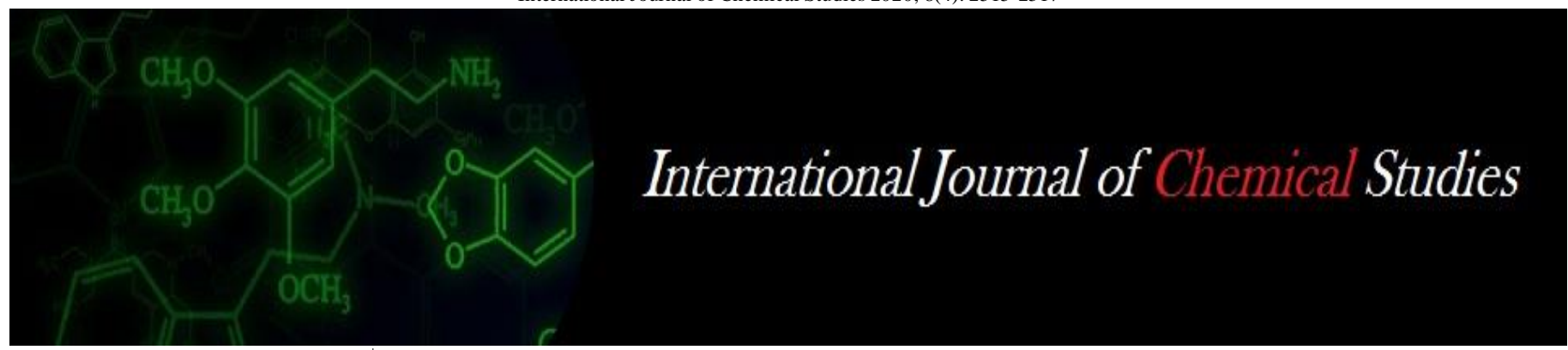

P-ISSN: 2349-8528

E-ISSN: 2321-4902

www.chemijournal.com

IJCS 2020; 8(4): 2515-2517

(C) 2020 IJCS

Received: 14-05-2020

Accepted: 16-06-2020

\section{Priyanka Dhage}

M.Sc., Genetics and plant

breeding, Dr. Panjabrao

Deshmukh Krishi Vidyapeeth,

Akola, Maharashtra, India

Dr. Ratnaparkhi RD

Associate Professor, Department

of Agricultural botany, Dr.

PDKV, Akola, Maharashtra,

India

\section{Madhavi Sonone}

Ph.D. Scholar, Plant Physiology,

Dr. Balasaheb Sawant Konkan

Krishi Vidyapeeth, Dapoli,

Maharashtra, India

\section{Sangita Fatak}

Senior Research Assistant, oil seed research unit, Dr. PDKV, Akola, Maharashtra, India

Corresponding Author: Priyanka Dhage

M.Sc., Genetics and plant breeding, Dr. Panjabrao

Deshmukh Krishi Vidyapeeth,

Akola, Maharashtra, India

\section{Correlation studies in safflower (Carthamus

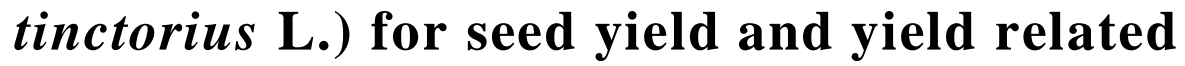 traits}

\author{
Priyanka Dhage, Dr. Ratnaparkhi RD, Madhavi Sonone and Sangita \\ Fatak
}

DOI: $\underline{\text { https://doi.org/10.22271/chemi.2020.v8.i4ac.10011 }}$

\begin{abstract}
The present study on " Correlation studies in safflower (Carthamus tinctorius L.) for seed yield and yield related traits" was undertaken to estimate the association of yield and yield contributing characters. The set of 63 genotypes along with three checks 'A-1, PBNS-12, PKV Pink' were evaluated at the field of Oilseeds Research Unit, Dr. PDKV, Akola during rabi 2018-2019.

Correlation studies revealed that, the seed yield per plant was significantly and positively correlated with plant height, number of branches per plant, number of capitula per plant, number of seeds per capitulum, 100 seed weight and volume weight whereas negatively and non significantly with days to 50\% flowering, days to maturity and oil content.
\end{abstract}

Keywords: Correlation, safflower, seed yield

\section{Introduction}

Safflower (Carthamus tinctorius L.) is one of the oldest oilseed crops and is widely grown under the hot, dry climate of the Middle East, the centre of its origin and diversity. It belongs to the family Compositeae or Asteraceae. In the wild genus Carthamus is reported to have 25 species (Yuan et al., 1989) ${ }^{[15]}$. Amongst the species of Carthamus, only safflower (Carthamus tinctorius L.) is grown worldwide containing 24 pairs of chromosomes. Safflower flowers are known to have many medicinal properties for curing several chronic diseases and they are widely used in Chinese herbal preparations (Li and Mundel, 1996) ${ }^{[6]}$. It is an important oilseed crop as it contains 78 per cent of PUFA (Linoleic Acid) which is useful for heart patients as it reduces blood cholesterol levels (Nimbkar 2002) ${ }^{[8]}$. It also contains $16-20$ per cent mono saturated fatty acid (Oleic Acid) and only 8 per cent saturated fatty acid 2-3 per cent stearic acid, 6-8 per cent palmitic acid (Hamdan et al., 2011) ${ }^{[4]}$. Improvement in the seed yield per plant is an important activity of plant breeding. The ultimate seed yield is a complex process that will be affected by many genetic and non-genetic factors. Correlation coefficient is an important statistical constant which indicate the degree of association among the various characters. In order to know the magnitude of association of the seed yield with other yield influencing traits, correlation analysis is an effective tool. This will help in constructing a suitable plant type and combining desirable expression of different yield components. The present investigation therefore was planned to evaluate the genetic correlation studies in germplasm accessions of safflower.

\section{Material and methodology}

The experimental material consisted of 63 germplasm lines of safflower along with three checks A-1, PBNS-12 and PKV Pink. These were evaluated in augmented design, in a single row plot of five metre length at the field of Oilseeds Research Unit, Dr. Panjabrao Deshmukh Krishi Vidyapeeth, Akola, during rabi season 2018-19. The experimental design consisted of seven block design with each block containing nine germplasm lines and three checks. Checks were common for every block. All recommended cultural practices were followed to raise a good crop. The observations were recorded on five randomly selected plants for ten quantitative traits viz., days to $50 \%$ flowering, days to maturity, plant height $(\mathrm{cm})$, number of 
branches per plant, number of capitula per plant, number of seeds per capitulum, volume weight $(\mathrm{g} / 100 \mathrm{ml}), 100$ seed weight (g), oil content (\%) and seed yield per plant $(\mathrm{g})$. The data were subjected to simple correlation analysis as per Singh and Choudhary (1977) ${ }^{[14]}$.

\section{Result and discussion}

Genetic variability and correlation among seed yield and yield attributes help in identifying a suitable genotype with desired characteristics. This study aimed at selecting such desirable genotypes. The success of selection depends on the choice of selection criteria for improvement of seed yield. Correlation coefficient analysis could indicate significant relationship among the evaluated traits. The correlation coefficient between ten traits is presented in table 1 .

Correlation analysis showed that days to $50 \%$ flowering ($0.10)$ and days to maturity (-0.05) were negatively correlated with seed yield per plant. These results were in conformity with the results obtained by Anjani (2005) ${ }^{[1]}$, Salunkhe (2014) [12].

Plant height $(0.30 *)$ had significant positive association with seed yield per plant. Number of branches per plant $\left(0.38^{* *}\right)$ was significantly and positively correlated with seed yield per plant. similar results recorded by Pavithra (2016) [10], Semahegn et al. $(2016)^{[13]}$, Salunkhe $(2014)^{[12]}$.
Positive and significant association of number of capitula per plant $(0.72 * *)$ with seed yield was obtained. These results were in conformity with the results obtained by Pattar (2014) ${ }^{\text {[9] }}$, Gujar (2018) ${ }^{[2]}$ and Mohamed (2018) ${ }^{[7]}$.

Number of seeds per capitulum $(0.32 * *)$ was positively and significantly associated with seed yield per plant. Similar results were obtained by Pushpavalli et al. (2017) ${ }^{[1]}$ and Mohamed (2018) ${ }^{[7]}$.

Significant positive association between 100 seed weight $(0.39 * *)$ and seed yield per plant was obtained. Pushpavalli et al. (2017) ${ }^{[11]}$, Gujar (2018) ${ }^{[2]}$, Jadhav et al. $(2018)^{[5]}$ obtained similar results.

Volume weight $(0.47 * *)$ was positively and significantly associated with seed yield per plant.

Negative and non-significant association of oil content (-0.18) with seed yield per plant was observed. Existence of strong negative association between these components was also reported by Hoshang et al. (2013) ${ }^{[3]}$, Salunkhe (2014) ${ }^{[12]}$ and Pattar (2014) ${ }^{[9]}$. The special breeding strategies such as reciprocal recurrent selection are to be adopted for simultaneous improvement of both the traits

This study also indicates that a high yield in general correlate with low oil content. However, a genotype with both high yield and high oil content could be more useful for strengthening breeding programme.

Table 1: Simple correlation among ten yield contributing characters of safflower genotypes

\begin{tabular}{|c|c|c|c|c|c|c|c|c|c|c|}
\hline & $\begin{array}{c}\text { Days to } 50 \% \\
\text { flowering }\end{array}$ & $\begin{array}{c}\text { Days to } \\
\text { maturity }\end{array}$ & \begin{tabular}{|c|} 
Plant \\
height \\
$(\mathbf{c m})$
\end{tabular} & $\begin{array}{c}\text { No. of } \\
\text { branches/ } \\
\text { plant }\end{array}$ & $\begin{array}{c}\text { No. of } \\
\text { capitula/ } \\
\text { plant }\end{array}$ & \begin{tabular}{|c|} 
No. of \\
seeds/ \\
capitulum
\end{tabular} & $\begin{array}{l}100 \text { seed } \\
\text { wt. } \\
\text { (g) }\end{array}$ & $\begin{array}{l}\text { Volume wt. } \\
(\mathrm{g} / 100 \mathrm{ml})\end{array}$ & $\begin{array}{c}\text { Oil } \\
\text { content } \\
(\%)\end{array}$ & $\begin{array}{c}\text { Seed } \\
\text { yield/ } \\
\text { plant }(\mathrm{g})\end{array}$ \\
\hline Days to $50 \%$ flowering & 1.00 & 0.60 & $0.28^{*}$ & -0.03 & -0.16 & 0.22 & -0.05 & $-0.28^{*}$ & $0.42 * *$ & -0.10 \\
\hline Days to maturity & & 1.00 & $0.25^{*}$ & 0.14 & -0.02 & 0.08 & 0.03 & -0.10 & $0.34 * *$ & -0.05 \\
\hline Plant height $(\mathrm{cm})$ & & & 1.00 & 0.21 & 0.21 & $0.39 * *$ & 0.08 & 0.21 & $0.31 *$ & $0.30 *$ \\
\hline No. of branches/plant & & & & 1.00 & $0.37 * *$ & $0.25^{*}$ & -0.03 & $0.32 * *$ & 0.09 & $0.38 * *$ \\
\hline No. of capitula/plant & & & & & 1.00 & 0.23 & $0.30 *$ & $0.41 * *$ & -0.16 & $0.72 * *$ \\
\hline No. of seeds/capitulum & & & & & & 1.00 & -0.02 & 0.15 & 0.17 & $0.32 * *$ \\
\hline 100 seed weight $(\mathrm{g})$ & & & & & & & 1.00 & $0.33 * *$ & $-0.31 *$ & $0.39 * *$ \\
\hline Volume weight $(\mathrm{g} / 100 \mathrm{ml})$ & & & & & & & & 1.00 & -0.08 & $0.47 * *$ \\
\hline Oil content $(\%)$ & & & & & & & & & 1.00 & -0.18 \\
\hline Seed yield/ plant $(\mathrm{g})$ & & & & & & & & & & 1.00 \\
\hline
\end{tabular}

Note-* Significance at $5 \%$ level

$* *$ Significance at $1 \%$ level

\section{References}

1. Anjani. Genetic variability and character association in wild safflower (C. oxycantha) Ind. J. agric. Res. 2005; 75(8):516-518.

2. Gujar M. Genetic diversity for yield and its attributes in safflower (Carthamus tinctorius L.). M. Sc. (Agri) thesis submitted to Rajmata Vijayaraje Scindia Krishi Vishwa Vidyalay, Gwalior, 2018.

3. Hoshang N, Abas S, Rahim N, Samira N. Study of correlation between important agronomic traits and path analysis for grain and oil yield in safflower. International Journal of Agronomy and plant production. 2013; 4(4):670-673.

4. Hamdan YAS, Gracia-moreno MJ, Redondo-nevado L Velasco, Pe rez-vich B. Development and characterization of genomic microsatellite markers in safflower (Carthamus tinctorius L.). Plant Breeding. 2011; 130:237-241.

5. Jadhav SA, Dhuppe MV, Salunke PM. Correlation coefficient and path analysis in safflower (Carthamus tinctorius L.). International Journal of Current Microbiology and Applied Sciences. 2018; 6:1234-1241.
6. Li D, Mundel HH. Safflower. (Carthamus tinctorius L.). Promoting the Conservation and Use of Underutilized and Neglected Crops.7. Institute of Plant Genetics and Crop Plant Research, Gatersleben / International Plant Genetic Resources Institute, Rome, 1996, 83p.

7. Mohamed KA, Elmogtba EFY. Genetic variability and inter-relationship for yield and its components in safflower (Carthamus tinctorius L.). Asian Research Journal of Agriculture. 2018; 8(4):1-7.

8. Nimbkar N. Safflower rediscovered. Times Agril J. 2002; 2(1):32-36.

9. Pattar V. Genetic studies in new safflower (Carthamus tinctorius $L$.). genotypes M Sc. Thesis submitted to UAS Dharwad, 2014.

10. Pavithra K, Patil R, Harijan Y, Nishanth G. Correlation and Path Analysis Studies in Safflower (Carthamus tinctorius L.) Germplasm Res. J. of Agri. Sci. 2016; 7(2):428-432.

11. Pushpavalli SNCVL, Reddy TR, Kumar G, Sudhakar C. Genetic divergence, correlation and path analysis for the yield components of safflower genotypes (Carthamus tinctorius L.). Life Sciences International Research Journal. 2017; 4(1):98-102. 
12. Salunkhe DS. Assessment of genetic divergence in safflower (Carthamus tinctorious L.) M. Sc. Thesis submitted to MPKV, Rahuri, 2014.

13. Semahegn Y, Tesfaye M. Characters Associations and Path Analysis in Safflower (Carthamus tinctorious L.) Accessions, Molecular Plant Breeding. 2016; 7(31):1-5.

14. Singh R, Choudary B. Biometrical methods in quantitative genetic analysis. Kalyani pub., Ludhiana. 1977; 54:224-252.

15. Yuan Guobi, Han Yunzhou, Li Dajue. Safflower germplasm and its exploitation and utilization. Science Press, 1989, 344p. 